\title{
Distribution of CAMP and CAMP-Dependent Protein Kinases in Aplysia Sensory Neurons
}

\author{
Steven M. Greenberg, Lise Bernier, and James H. Schwartz \\ Howard Hughes Medical Institute, Center for Neurobiology and Behavior, Columbia University, New York, New York \\ 10032
}

Sensitization of the gill- and siphon-withdrawal reflex in Aplysia is considered a simple form of learning. Previous work has provided physiological and pharmacological evidence that CAMP-dependent protein phosphorylation within identified sensory neurons of the abdominal ganglion underlies the short-term form of this behavioral modification. Our main goal in this paper is to determine the subcellular distribution of CAMP and to measure the amounts and properties of the 2 types of subunits (regulatory and catalytic) that constitute the CAMP-dependent protein kinase. Do these biochemical parameters differ in sensory cells from those in other parts of nervous tissue? We found that the increased CAMP synthesized under conditions of sensitization is distributed in 3 compartments in the neuron: most of it is free in the cytoplasm; the remainder is bound either to cytoplasmic or to particulate proteins, which are believed to be regulatory subunits of the CAMP-dependent protein kinase. Binding of CAMP within the neurons is a measure of activation of the kinase. At rest, $17 \%$ of the binding sites in sensory cells were occupied. After brief electrical stimulation of the connective, which released endogenous transmitter, occupancy increased to $34 \%$. This treatment increased the amount of CAMP bound to the various binding proteins differentially. The biochemical characteristics of cAMP binding were found to be the same in sensory neurons as in the rest of the nervous system but different from those in muscle. Thus, memory and learning are likely to be mediated by enzymes that are shared by other nerve cells. We found that sensory neurons have greater cAMP-dependent protein kinase activity than other neurons, however, and as a result may be more sensitive to small increases of CAMP.

There is now much evidence indicating that alterations in the synthesis of cAMP and consequent changes in protein phosphorylation within specific neurons underlie several simple forms of learning in invertebrates, for example, short-term sensitization of the gill- and siphon-withdrawal reflex in Aplysia (Kandel

\footnotetext{
Received Apr. 3, 1986; revised June 25, 1986; accepted June 26, 1986.

We are grateful to Mark Bitensky for insisting that we distinguish between free and bound cAMP. We thank Eli Shapiro for collaborating in the electrophysiological experiments and Janice Dahms for capable technical assistance. We also thank Drs. Shapiro, Tom Abrams, and Eric Kandel for reading the manuscript critically, Edmund Davys for preparing the manuscript, and Robin Tewes, the figures.

Correspondence should be addressed to James H. Schwartz, M.D., Ph.D., Howard Hughes Medical Institute, Research Annex/Room 708, 722 West 168th Street, New York, NY 10032.
}

Copyright (C) 1987 Society for Neuroscience $0270-6474 / 87 / 010291-11 \$ 02.00 / 0$ and Schwartz, 1982). Although the ability to mediate learning is likely to be a specialized function of particular nerve cells, the enzymes that catalyze the reactions of the cAMP cascade are present in most if not all neurons. How then can ubiquitous molecules, which are universally distributed and are known to regulate many different metabolic pathways, be used by some neurons to accomplish so specialized a function as the modification of an animal's bchavior?

Sensitization has been shown to be the consequence of presynaptic facilitation that results from the augmented release of transmitter from sensory neurons of the abdominal ganglion onto interneurons and motor neurons innervating the muscles that cause the gill and siphon to contract (Castellucci and Kandel, 1976; Klein and Kandel, 1978; Kandel and Schwartz, 1982). Reflex withdrawal of the tail is mediated by a population of sensory neurons in the pleural ganglion (Walters et al., 1983) with morphological and biophysical properties similar to those of the sensory cells in the abdominal ganglion (Pollock et al., 1985). Direct measurements in sensory cells have revealed that the enhanced synthesis of cAMP, which is produced by applying 5-HT or the small cardiac peptides (SCP) neuropeptides or by activating facilitating neurons with the release of the natural (endogenous) facilitating transmitter, persists for 15 to $30 \mathrm{~min}$ (Bernier et al., 1982; Abrams et al., 1984). Castellucci et al. (1980, 1982) have presented evidence that the sustained synthesis of cAMP in sensory cells, which maintains the protein kinase in an active form, accounts for the time course of the memory for short-term sensitization.

It has been shown that cAMP activates the kinase by binding to regulatory subunits $(\mathrm{R})$ in the following reaction:

$$
4 \mathrm{cAMP}+\mathrm{R}_{2} \mathrm{C}_{2} \rightleftharpoons 2 \mathrm{C}+2(\mathrm{R} \cdot \mathrm{cAMP})
$$

thereby releasing the catalytic subunits (C) from inhibition (Flockhart and Corbin, 1982; Nestler and Greengard, 1984). In vertebrate nervous tissue, the only proteins that bind cAMP are regulatory subunits of the cAMP-dependent protein kinase (Walter et al., 1977, 1978). In those animals, the extent to which cAMP is bound therefore reflects the activation of these kinases, and the intracellular distribution of bound cAMP can provide insight into the compartments of the cell affected by the transmitter. In Aplysia nervous tissue, Eppler et al. (1982) identified 5 major cAMP-binding proteins by photoaffinity labeling with ${ }^{32} \mathrm{P}-8-\mathrm{N}_{3} \mathrm{CAMP}$. Although the subcellular distribution and the regional assortment of these binding proteins differ, the 5 proteins appear to be closely related in structure and to serve as regulatory subunits of the CAMP-dependent protein kinase (Eppler et al., 1986). In this paper, we determine how much cAMP 


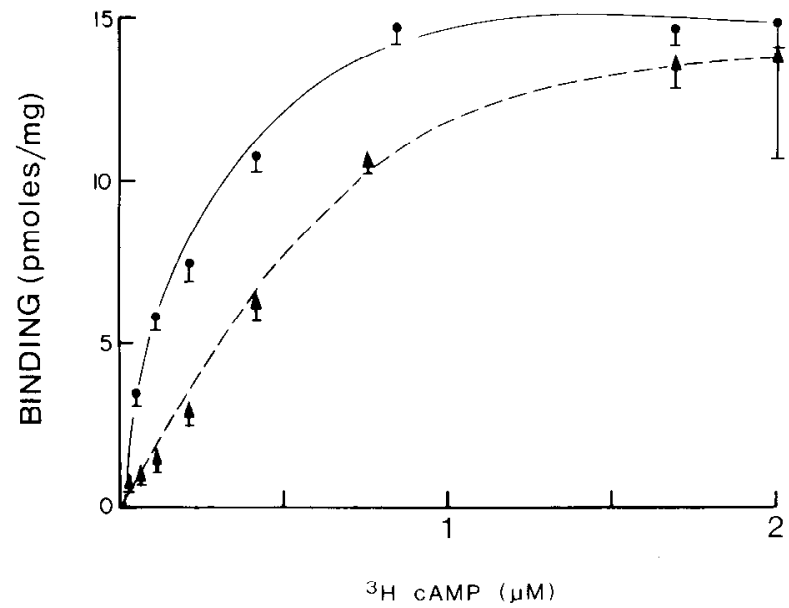

Figure 1. Binding of ${ }^{3} \mathrm{H}-\mathrm{cAMP}$ in a homogenate of Aplysia neural components was measured after $10 \mathrm{~min}$ at room temperature in potassium phosphate $(\mathrm{pH} 6.8)$. Bound ${ }^{3} \mathrm{H}-\mathrm{cAMP}$ was separated by filtration through nitrocellulose. The solid line, fit to the data points by eye, represents binding in homogenates from ganglia that had not been exposed to 5-HT. Each point is the average of 3 separate, triplicate determinations with $40 \mu \mathrm{g}$ of protein. The dashed line represents binding in neural components from ganglia treated for $5 \mathrm{~min}$ with $2 \times 10^{-4} \mathrm{M}$ 5-HT before homogenization. Each point is the average of 2 determinations in triplicate. Maximum binding occurs at $3 \mathrm{~min}$ at room temperature. Incubation in the presence of a 20 -fold excess of cold cAMP reduces the binding to values obtained on filters in the absence of added protein.

is bound to protein and how much is free in sensory neurons at rest and under conditions of sensitization. We also examine the distributions of cAMP binding and cAMP-dependent protein kinase activity in sensory neurons and in other Aplysia cells and tissues, and we study the characteristics of the binding reaction both in vitro and in intact sensory neurons within the isolated ganglion.

\section{Materials and Methods}

Animals and tissues. Aplysia californica weighing 90-125 gm (supplied from California by the Pacific Biomarine Company, Venice; Sea Life Supply, Sand City; Marine Specimens Unlimited, Pacific Palisades; and the Howard Hughes Medical Institute's Mariculture Resource Facility, Woods Hole Oceanographic Institute at Woods Hole, MA) were kept at $15^{\circ} \mathrm{C}$ in artificial seawater (Instant Ocean, Aquarium Systems, Mentor, $\mathrm{OH}$ ). Abdominal and pleuropedal ganglia with nerves attached were removed through an incision in the foot from animals anesthetized by injection of a volume of isotonic $\mathrm{MgCl}_{2}$ corresponding to one-half the weight of the animal. Ganglia were pinned to silicone plastic (Sylgard, Dow Corning Co., Midland, MI) in high $\mathrm{Mg}^{2+}$ seawater (Byrne et al., 1974) to minimize any effects of mechanical stimulation. After they were pinned, the ganglia were washed several times and then kept at $15^{\circ} \mathrm{C}$ for at least $30 \mathrm{~min}$ in artificial seawater supplemented with amino acid and vitamins (Eisenstadt et al., 1973) containing $P_{i}$ at a concentration of about $5 \mu \mathrm{M}$ (Bernier et al., 1982).

Exposure to ${ }^{32} \mathrm{P}_{\mathrm{i}}$. Ganglia were exposed at $15^{\circ} \mathrm{C}$ to $0.5 \mathrm{mCi}$ of ${ }^{32} \mathrm{P}_{\mathrm{i}}$ (Amersham, Arlington Heights, IL, orthophosphate, carrier free), each in a $0.5 \mathrm{ml}$ droplet of the supplemented artificial seawater for $3 \mathrm{hr}$ (Bernier et al., 1982). The ganglia were washed and maintained in fresh seawater for an additional $18-22 \mathrm{hr}$ in order to label phosphorylated intermediates stably.

Stimulation. In one series of experiments, abdominal ganglia were exposed for $5 \mathrm{~min}$ to $0.2 \mathrm{~mm} 5$-HT creatinine sulfate (Sigma Chemicals Co., St. Louis, MO). This saturating concentration has previously been used to ensure maximal stimulation of adenylate cyclase in Aplysia ganglia (Cedar and Schwartz, 1972) and sensory neurons (Bernier et al., 1982). In another series, facilitating interneurons (Hawkins et al., 1981) were stimulated extracellularly by shocking the left connective through a suction electrode (10 sec train, $6 \mathrm{~Hz}, 3 \mathrm{msec}, 6 \mathrm{~V}$ pulses) (Hawkins et al., 1981) while recording intracellularly from one sensory cell of the abdominal cluster. The efficacy of nerve stimulation was assessed by measuring how much the spike broadened in sensory cells; increased spike broadening accompanies presynaptic facilitation. $\Lambda 2 \mathrm{sec}$ train of suprathreshold intracellular pulses $(20 \mathrm{~Hz})$ was used to inactivate the nonmodulated $\mathrm{K}^{+}$currents of spikes in sensory neurons and thus enhance spike-broadening during facilitation (M. Klein, personal communication). The duration of the last spike in a train was measured both before nerve stimulation and $20 \mathrm{sec}$ thereafter; in all successfully stimulated ganglia the spike broadened by more than $35 \%$. The ganglia were frozen for dissection $10 \mathrm{sec}$ later.

Methods of dissection. Ganglia were frozen quickly at $-20^{\circ} \mathrm{C}$ in propylene glycol: $2 \mathrm{M} \mathrm{NaCl}(1: 1, \mathrm{vol} / \mathrm{vol})$; cell bodies of abdominal (Byrne et al., 1974) and pleural (Walters et al., 1983) sensory neurons were identified by their position and characteristic appearance, and were dissected out on powdered solid $\mathrm{CO}_{2}$ as previously described by Bernier et al. (1982). In some experiments, the frozen neural components were sorted by dissection into 2 fractions enriched either in cell bodies or in neuropil (Eppler et al., 1982).

\section{Preparations and assays}

Membrane-cytoskeleton fraction. Neural components from a single ganglion were extracted in a $25 \mu \mathrm{l}$ volume of $2 \mathrm{M}$ glycerol, $1 \mathrm{mM} \mathrm{MgSO}_{4}$, $2 \mathrm{~mm}$ EGTA, $0.2 \%$ saponin, $0.02 \% \mathrm{Na}$ azide, and $0.1 \mathrm{M} \mathrm{K-PIPES} \mathrm{(pH}$ 6.9 ), and centrifuged at $7000 \times g$ for $15 \mathrm{~min}$ at $4^{\circ} \mathrm{C}$ (Saitoh and Schwartz, 1983). The resulting pellet was vortexed in another $25 \mu \mathrm{l}$ volume and centrifuged again. The combined supernatants constitute the cytosol fraction. The pellet, suspended in $50 \mu \mathrm{l}$, constitutes the membranecytoskeleton fraction.

$c A M P$. Dissected neural components from ganglia that had been exposed to ${ }^{32} \mathrm{P}_{\mathrm{i}}$ were transferred while still frozen to a glass-glass homogenizer (Micrometric Instruments, Cleveland, $\mathrm{OH}$ ) containing $0.25 \mathrm{ml}$ of $50 \%$ aqueous ethanol at $0^{\circ} \mathrm{C}$ with $0.2 \mu \mathrm{g}$ of cAMP (sodium salt, Sigma) added to measure recovery. cAMP was isolated by thin-layer chromatography on polyethylimine plates, and ${ }^{32}$ P-ATP and AMP were separated from each other and from $\mathrm{P}_{\mathrm{i}}$ and $\mathrm{PP}_{\mathrm{i}}$ by high-voltage electrophoresis (Bernier et al., 1982). The content of labeled cAMP is calculated as a percentage of ${ }^{32} \mathrm{P}$-ATP: knowing the specific activity of ${ }^{32} \mathrm{P}_{\mathrm{i}}$ in the seawater, it is possible to estimate the amount of labeled ATP, presuming that the labeled ATP is completely equilibrated (Ambron et al., 1975; Bernier et al., 1982).

Homogenates for the binding assay. Neural components from the central ganglia of one animal were suspended in $0.5 \mathrm{ml}$ of $0.3 \mathrm{M} \mathrm{NaCl}$, $0.2 \mathrm{~m}$ sucrose, $3 \mathrm{~mm}$ EDTA, $1 \mathrm{~mm}$ EGTA, 0.1\% NP-40, and $20 \mathrm{~mm}$ Tris- $\mathrm{HCl}(\mathrm{pH} 7.4)$ in a glass tissue grinder. After homogenization, the sample was centrifuged at $105,000 \times g$ for $30 \mathrm{~min}$. The supernatant is the soluble fraction. The pellet was suspended and homogenized again in an equal volume of the same buffer, to become the particulate fraction. The volume used for homogenization can be reduced for smaller samples: For example, 2 clusters of sensory neurons dissected from the pleural ganglion were homogenized in $0.1 \mathrm{ml}$. This procedure was also used to prepare a soluble fraction of buccal muscle.

Embryo homogenates. Aplysia egg masses were frozen in liquid nitrogen and pounded to powder in a mortar chillcd to $70^{\circ} \mathrm{C}$. The powder was suspended in $0.35 \mathrm{~m}$ sucrose, $0.17 \mathrm{M} \mathrm{NaCl}, 3 \mathrm{~mm}$ EDTA, $1 \mathrm{~mm}$ EGTA, $0.1 \%$ NP-40, $5 \mathrm{~mm}$ 2-mercaptoethanol, $20 \mathrm{~mm}$ benzamidine (Sigma), and $20 \mathrm{~mm}$ Tris-HCl (pH 7.4) and filtered through 3 layers of cheesecloth. The protein concentration in the filtrate was between 2 and $5 \mathrm{mg} / \mathrm{ml}$.

cAMP-dependent protein kinase. The dissected neural components were homogenized in $0.1 \mathrm{M} \mathrm{NaCl}, 3 \mathrm{~mm}$ EDTA, $1 \mathrm{~mm}$ EGTA, $5 \mathrm{~mm}$ 2-mercaptoethanol, and $20 \mathrm{~mm}$ Tris- $\mathrm{HCl}(\mathrm{pH}$ 7.4). Kinase activity was determined by phosphorylation of a synthetic heptapeptide (Kemptide, Sigma), with slight modification from our previously described method (Eppler et al., 1986). To mitigate the effect of any endogenous inhibitors (Hofmann et al., 1977), kinase activity was determined at several dilutions of the homogenate in $0.5 \mathrm{mg} / \mathrm{ml} \mathrm{BSA} \mathrm{(crystallized;} \mathrm{Sigma)} \mathrm{and}$ $5 \mathrm{~mm} 2$-mercaptocthanol. The specific activities expressed are derived from the plateau values obtained with dilution. Activity is calculated as the difference between ${ }^{32} \mathrm{P}$-phosphorus incorporated into the heptapeptide in the presence of $10 \mu \mathrm{M}$ CAMP and that in the presence of protein kinase inhibitor $(0.1 \mathrm{mg} / \mathrm{ml}$, Sigma; Type II).

CAMP-binding proteins. cAMP bound to protein was measured by filter assay (Sugden and Corbin, 1976): $50 \mu$ l homogenates of Aplysia 


\begin{tabular}{|c|c|c|}
\hline \multirow[b]{2}{*}{ Neurons } & \multicolumn{2}{|c|}{ cAMP (pmol/mg protein) } \\
\hline & Frcc & Bound \\
\hline \multicolumn{3}{|l|}{ Sensory cells } \\
\hline No treatment & $16.3 \pm 3.4$ & $3.0 \pm 0.03$ \\
\hline 5-HT & $47.3 \pm 9.6$ & $6.0 \pm 0.8$ \\
\hline Extent of stimulation & 2.9 & 2.0 \\
\hline \multicolumn{3}{|l|}{ Central ganglia } \\
\hline No treatment & $20.3 \pm 2.9$ & $2.1 \pm 0.4$ \\
\hline $5-\mathrm{HT}$ & $47.8 \pm 3.9$ & $7.8 \pm 0.6$ \\
\hline Extent of stimulation & 2.4 & 3.7 \\
\hline
\end{tabular}

Values of cAMP both free and bound (soluble plus particulate) were calculated from the ${ }^{32} \mathrm{P}-\mathrm{ATP}$ present in the samples, assuming complete equilibration of the label in ATP (Bernier et al., 1982) and values of ATP measured previously (Ambron et al., 1975). cAMP was measured in sensory cell clusters from 5 pleural ganglia and 5 abdominal ganglia for each condition.

neural components containing 5-100 $\mu \mathrm{g}$ of protein were incubated for 10 min at $22^{\circ} \mathrm{C}$ with $5,8{ }^{3} \mathrm{H}$-adcnosine $3^{\prime}, 5^{\prime}$-cyclic monophosphate (56 $\mathrm{Ci} / \mathrm{mmol}$, Amersham) in $0.1 \mathrm{ml}$ containing $0.5 \mathrm{mg} / \mathrm{ml}$ histone IIa, 1 mм IBMX, $1 \mathrm{~mm}$ theophylline (all from Sigma), $2 \mathrm{~m} \mathrm{NaCl}, 1 \mathrm{~mm}$ EDTA, and $50 \mathrm{~mm}$ potassium phosphate $(\mathrm{pH} \mathrm{6.8)}$. The reaction was stopped by adding $2.6 \mathrm{ml}$ of cold $10 \mathrm{~mm}$ potassium phosphate, $1 \mathrm{~mm}$ EDTA (pH 6.8). A period of $10 \mathrm{~min}$ was chosen, although binding reached a maximum at $3 \mathrm{~min}$ and remained constant for $30 \mathrm{~min}$, decreasing slightly thereafter (Bernier, 1984). After incubation, the mixture was filtered through a moistened $0.45 \mu \mathrm{m}$ nitrocellulose filter (HAWP, Millipore Corp., Bedford, MA). The tubes were rinsed with $2.6 \mathrm{ml}$ of the buffer and the filter washed 3 more times (total wash, $13 \mathrm{ml}$ ). The filters were dried overnight at room temperature, and radioactivity was measured by scintillation counting. To assay for total cAMP-binding activity in extracts we used $2.2 \mu \mathrm{M}{ }^{3} \mathrm{H}$-cAMP because this concentration is saturating even after stimulation of endogenous c $\Lambda \mathrm{MP}$ synthesis by 5-HT (Fig. 1). The binding of ${ }^{3} \mathrm{H}-\mathrm{cAMP}$ to protein in Aplysia homogenates and its retention by the filter was proportional to the amount of protein added from $5 \mu \mathrm{g}$ to $>140 \mu \mathrm{g}$. Addition of $0.1 \mathrm{mM}$ AMP did not influence the binding of ${ }^{3} \mathrm{H}$-cAMP. Nonspecific binding was assessed by determining the amounts of ${ }^{3} \mathrm{H}$-cAMP retained in the presence of a 20 -fold excess of unlabeled cyclic nucleotide, and was $1.0 \mathrm{pmol}$. This amount was retained by the filter both in the presence and in the absence of a protein sample.

Photoaffinity-labeling of $c A M P$-binding proteins. Labeling with ${ }^{32} \mathrm{P}$ 8- $\mathrm{N}_{3} \mathrm{cAMP}(50-80 \mathrm{Ci} / \mathrm{mmol}$, ICN, Irvine, CA) was carried out by a modification of the procedure of Eppler et al. (1982). Equal portions of homogenate were made $0.2 \%$ saponin and first incubated with $1.0 \mu \mathrm{M}$ ${ }^{32} \mathrm{P}-8-\mathrm{N}_{3} \mathrm{CAMP}$ at $0^{\circ} \mathrm{C}$ or $22^{\circ} \mathrm{C}$ for $10 \mathrm{~min}$ followed by a further $10 \mathrm{~min}$ equilibrium period at $0^{\circ} \mathrm{C}$. The samples were then exposed at $0^{\circ} \mathrm{C}$ for $10 \mathrm{~min}$ to ultraviolet light. Proteins were separated by SDS-PAGE, stained with silver (Bio-Rad), and autoradiographed at $-70^{\circ} \mathrm{C}$ (Eppler et al., 1986).

Separation of bound and free CAMP. Ganglia or isolated cells were homogenized for $5 \mathrm{sec}$ at $0^{\circ} \mathrm{C}$ in a volume of $0.1-0.5 \mathrm{ml}$ (depending on the amount of tissue used) containing $0.3 \mathrm{M} \mathrm{NaCl}, 0.2 \mathrm{M}$ sucrose, $3 \mathrm{~mm}$ EDTA, $1 \mathrm{~mm}$ EGTA, and $20 \mathrm{~mm}$ Tris- $\mathrm{HCl}$ (pH 7.4). Under these conditions, loss of bound cAMP is negligible: $3.5 \%$ in $30 \mathrm{~min}$, with a halflife of $7 \mathrm{hr}$ (Bernier, 1984). A sample was removed to measure total cAMP in order to evaluate any loss that might occur during the separation of bound and free cAMP by procedures modified from Terasaki and Brooker (1977). (The sum of free and bound cAMP equaled the total measured cAMP: in 10 experiments, the recovery was $103 \pm 10 \%$ for abdominal ganglia and $88 \pm 6 \%$ for sensory neurons.) The remainder was diluted to $3 \mathrm{ml}$ and centrifuged at $105,000 \times g$ for $30 \mathrm{~min}$. cAMP bound to protein in the supernatant was separated from free cAMP by filtration through nitrocellulose. cAMP retained on the filter was eluted for 4-5 hr with $0.01 \mathrm{M} \mathrm{HCl}(2 \mathrm{ml})$. Particulate cAMP was extracted from the $105,000 \times g$ pellet with $0.01 \mathrm{M} \mathrm{HCl}(0.5 \mathrm{ml})$. All samples were evaporated to dryness and resuspended in $50 \%$ aqueous ethanol $(0.1$ $\mathrm{ml})$. The cAMP in all fractions was measured as described above.

Protein. Protein was determined using BSA as a standard (Lowry et al., 1951). The neuronal components from the 5 major central ganglia

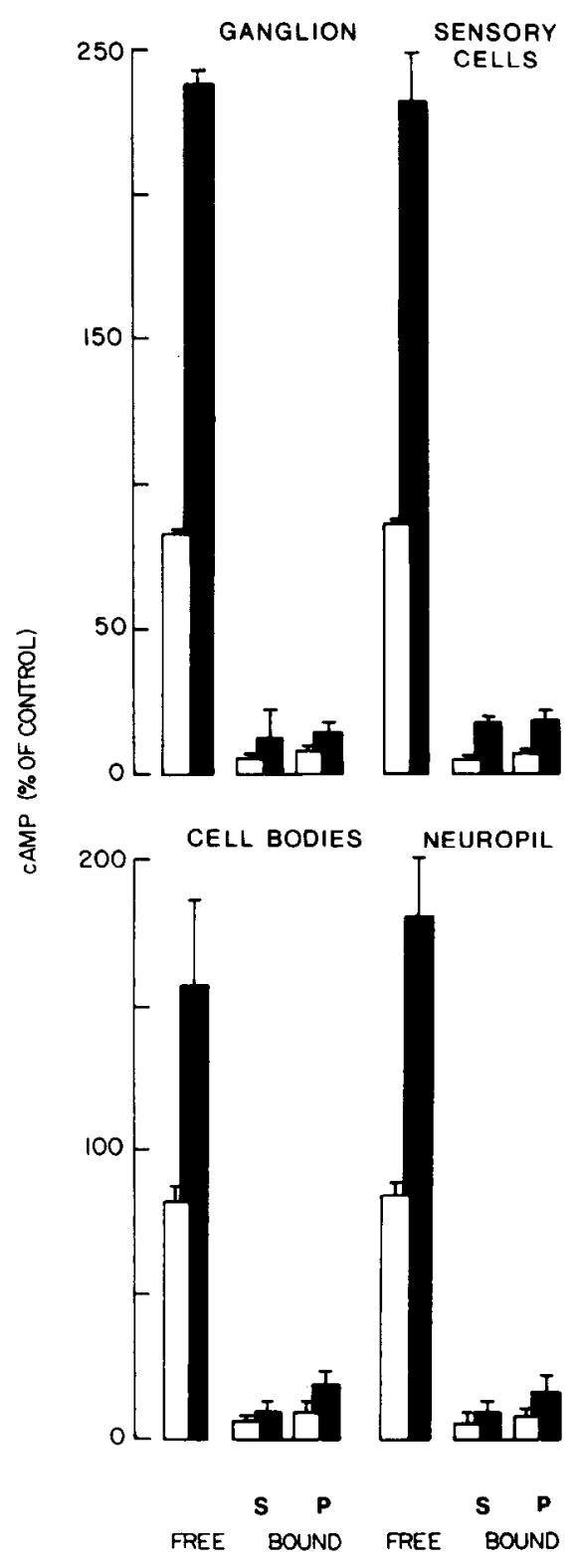

Figure 2. Distribution of cAMP in nervous tissue. cAMP was measured in neural components from abdominal ganglia labcled by exposure to ${ }^{32} \mathrm{P}_{\mathrm{i}}$ (Bernier et al., 1982). Free and bound cAMP were separated as described in Materials and Methods from ganglia treated for $5 \mathrm{~min}$ with $2 \times 10^{-4}$ M 5-HT (open bars) and untreated controls (solid bars). The bound cAMP was distributed in 2 fractions: soluble $(S)$ and particulate $(P)$. The values, from 6 determinations, are expressed as a percentage of the total cAMP in the untreated ganglia.

of 1 animal's nervous system dissected from thcir conncctive tissue sheaths yielded $670 \pm 52 \mu \mathrm{g}(n=8)$ dry weight of protein. The neuronal components of a single abdominal ganglion yielded $148 \pm 32 \mu \mathrm{g}(n=$ 9), and a cluster of sensory neurons from the pleural ganglion yielded $5.7 \pm 0.6 \mu \mathrm{g}(n=10)$. For many of the determinations, we used sensory neurons from the pleural rather than from the abdominal ganglion because there are 10 times more cells in a pleural cluster.

\section{Results}

\section{Distribution of CAMP in sensory neurons}

Underlying sensitization of the gill- and siphon-withdrawal reflex is the elevation of cAMP within sensory neurons that results in the activation of CAMP-dependent protein kinase (see Bernier et al., 1982; Kandel and Schwartz, 1982). The concentration of 
Table 2. cAMP-binding and kinase activity in various parts of the Aplysia nervous system

\begin{tabular}{lrllll} 
Component & $\begin{array}{l}\text { Binding } \\
(\mathrm{nmol} / \mathrm{mg})\end{array}$ & $\begin{array}{l}\text { Kinase } \\
(\mathrm{nmol} / \mathrm{min} /\end{array}$ & Ratio $n$ \\
\hline $\begin{array}{l}\text { Central ganglia } \\
\quad \text { Total neural components }\end{array}$ & $12.8 \pm 1.3$ & $6.7 \pm 0.7$ & 1.9 & 7 \\
$\begin{array}{l}\text { Abdominal ganglion } \\
\quad \text { Cell bodies }\end{array}$ & $11.0 \pm 0.8$ & $3.2 \pm 0.2$ & 3.4 & 6 \\
$\quad \begin{array}{l}\text { Neuropil } \\
\text { Bag cells }\end{array}$ & $9.9 \pm 1.2$ & $7.4 \pm 0.7$ & 1.3 & 6 \\
$\begin{array}{l}\text { Pleural ganglion } \\
\quad \text { Sensory neurons }\end{array}$ & $15.6 \pm 0.9$ & - & - & 3 \\
$\quad \begin{array}{l}\text { Remaining neural } \\
\text { components }\end{array}$ & $12.7 \pm 0.6$ & $13.1 \pm 1.2$ & 1.0 & 10 \\
& $13.6 \pm 2.0$ & $6.9 \pm 0.7$ & 2.0 & 5
\end{tabular}

The maximum binding capacity present in the various parts was assayed at $22^{\circ} \mathrm{C}$ using a saturating concentration $(2.2 \mu \mathrm{M})$ of ${ }^{3} \mathrm{H}$-cAMP as probe. Kinase activity was determined by phosphorylation of the synthetic heptapeptide (Materials and Methods). Values are the means $\pm \mathrm{SE}$ in $n$ separate, duplicate determinations. An arbitrary ratio between cAMP-binding proteins and kinase activity was obtained by dividing the binding measurements by the values of kinase activity.

cAMP, normally $20 \mathrm{pmol} / \mathrm{mg}$ protein in unstimulated sensory ncurons, incrcascs maximally 2- to 3 -fold $5 \mathrm{~min}$ after ganglia are exposed to $0.2 \mathrm{~mm}$ 5-HT (Table 1; and Bernier et al., 1982). What proportion of the elevated cAMP is bound to protein and how much is free? We found that most of the cAMP is free both in sensory neurons (Fig. $2 A$, Table 1 ) and in the total neuronal components from the abdominal ganglion (Fig. $2 B$ ). Less than $20 \%$ was associated with protein, and this proportion did not change appreciably after stimulation with $5-\mathrm{HT}$.

Some cAMP-binding proteins in Aplysia neural components have been shown to be associated with membrane or with cytoskeleton (particulate) fractions, and others to be unattached in the cytosol (soluble) (Eppler et al., 1982, 1986). We find that the cAMP bound to protein within the cell is distributed almost equally between the cytosolic and particulate fractions (Fig. $2 A$ ). We separated these 2 forms of bound cAMP in order to determine the distribution of cAMP between these 2 classes of binding proteins (see Materials and Methods). The bound cAMP in the cytosol was isolated by filtering the supernatant fraction through nitrocellulose: soluble cAMP-binding proteins adsorb to the filters. The bound cAMP associated with membranes was sedimented with the particulate fraction. The amounts of cAMP

Table 3. Regional distribution of cAMP-binding activity in the abdominal ganglion

$\%$ Total activity in ganglion

\begin{tabular}{lll} 
Fraction & Cell bodies & Neuropil \\
\hline Soluble & $28.5 \pm 2.7$ & $21.7 \pm 0.8$ \\
Particulate & $19.2 \pm 1.6$ & $29.0 \pm 1.8$ \\
\hline
\end{tabular}

Cell bodies and neuropil from 6 abdominal ganglia were sorted by hand and fractionated as described (Eppler et al., 1982; see Materials and Methods). Binding of cAMP was assayed on nitrocellulose filters and is presented as the percentage of the total binding activity in each fraction. The total activity in the neural components of the ganglion, obtained by summing the activities measured in the fractions (cell body and neuropil) in each of the 6 determinations, was $10.5 \pm 1$ $\mathrm{pmol} \mathrm{cAMP}$ bound $/ \mathrm{mg}$ protein. This did not differ from $11.1 \pm 0.9$, the value measured in 14 determinations on the unfractionated neural components of the ganglia.
Table 4. Subcellular distribution of cAMP-binding proteins

\begin{tabular}{|c|c|c|c|c|}
\hline \multirow{3}{*}{$\begin{array}{l}\text { Treat- } \\
\text { ment }\end{array}$} & \multicolumn{4}{|c|}{$\%$ Total binding activity } \\
\hline & \multicolumn{2}{|c|}{ Abdominal ganglion } & \multicolumn{2}{|c|}{ Sensory neurons } \\
\hline & Soluble & Particulate & Soluble & Particulate \\
\hline None & $54.8 \pm 3.7$ & $44.8 \pm 3.7$ & $51.4 \pm 1.1$ & $48.6 \pm 1.1$ \\
\hline 5-HT & $52.4 \pm 7.4$ & $47.2 \pm 7.4$ & $51.0 \pm 0.5$ & $49.0 \pm 0.5$ \\
\hline
\end{tabular}

Ganglia and cells were extracted with $0.2 \%$ saponin in $2 \mathrm{M}$ glycerol and the soluble and particulate (membrane-cytoskeleton complex) fractions prepared as described in Materials and Methods. cAMP-hinding activity in each fraction is given as the percentage of total binding activity (soluble and particulate) in the extract. Values are the means \pm SE of 4 separate determinations, each with 1 abdominal ganglion; 3 clusters from the pleural ganglia were combined for each sensory neuron determination.

in Figure 2 are reported as a percentage of the total cAMP in the control; in the neural components of the abdominal ganglion, this value corresponds to $2.6 \mathrm{pmol}$, and in individual sensory neurons, to $0.6 \mathrm{fmol}$. These values have been estimated from the proportion of ${ }^{32} \mathrm{P}$-ATP converted to cAMP assuming that complete equilibration of the alpha position of ATP had taken place (see legend to Table 1; and Bernier et al., 1982).

\section{Distribution of CAMP in regions of the abdominal ganglion}

The neural components from ganglia can be dissected by hand into 2 fractions, one enriched in neuronal cell bodies, the other in axons and nerve endings (neuropil) (Eppler et al., 1982). cAMP was partitioned similarly in fractions containing cell bodies (Fig. 2C) and neuropil regions of the abdominal ganglion (Fig. $2 D$ ). Only a small proportion of the cAMP in both of the fractions was bound to protein, and stimulation by 5-HT resulted in an increase in cAMP of the same extent in all of the fractions. Bound cAMP is similarly distributed between the soluble and particulate compartments in both regions.

\section{Distribution of binding activity and CAMP-dependent protein kinase activity in nervous tissue}

Our examination of cAMP's subcellular distribution within the neural components described above shows that there are protcins that bind cAMP within the cells, but it does not provide a measurement of how much total binding activity is actually present. We used nitrocellulose filters to determine the specific activity of cAMP binding in homogenates of sensory neurons and of the neural components from abdominal ganglia. These data are presented together with cAMP-dependent protein kinase activity in Table 2 . Sensory neurons have the same specific binding activity as other parts of nervous tissue.

We fractionated neural components in 2 other ways: first regionally, into cell-body and neuropil fractions, and, second, into membrane-cytoskeleton and supernatant fractions (Materials and Methods). Although the total cAMP-binding activity is equally distributed between cell bodies and nerve endings, the nerve-ending fraction appeared to be enriched in particulate binding activity (Table 3 ). The distribution of cAMP-binding proteins is similar between the cytoplasm and the membranecytoskeleton fraction (Table 4). Similar distributions of photoaffinity-labeled binding proteins in Aplysia nervous tissue have previously been described (Eppler et al., 1982, 1986). Treatment of abdominal ganglia with 5-HT did not change the proportion of binding proteins present in either compartment, nor did it change the total amounts of the binding proteins in the tissue. 


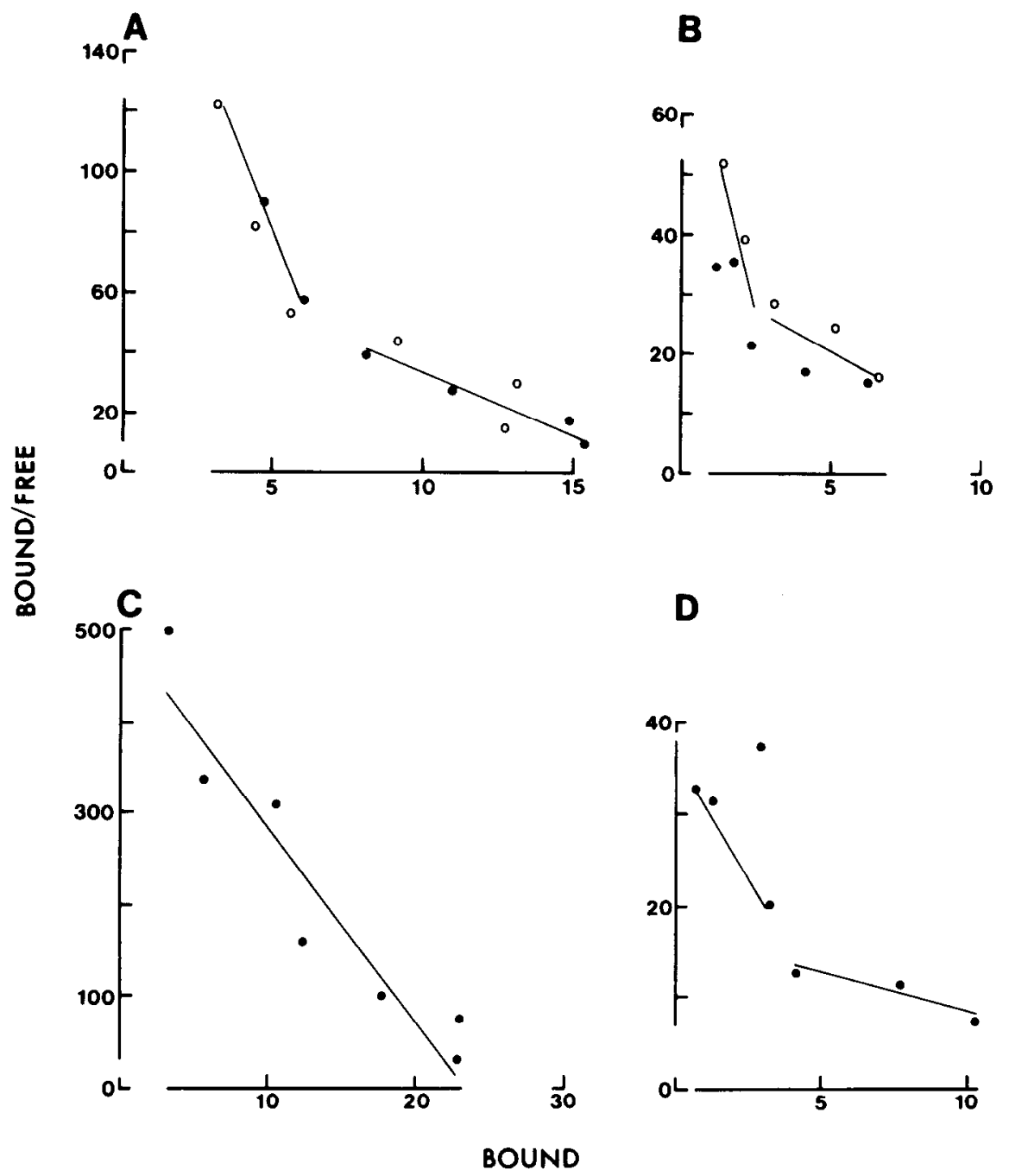

Figure 3. Scatchard plots of the dependence of binding on concentration of ${ }^{3} \mathrm{H}$-cAMP. Samples were incubated for $10 \mathrm{~min}$ at room temperature. Bound cAMP is calculated as $\mathrm{pmol} / \mathrm{mg}$ protein; free cAMP is the micromolar concentration. $A$ and $B$, Soluble $(A)$ and particulate $(B)$ fractions generated from neural components of all the central ganglia $(O)$ and from sensory neurons dissected from 34 pleural ganglia (०). Concentrations of cAMP varied from 0.26 to $1.7 \times 10^{-6} \mathrm{M}$. $C$, Fibers from buccal muscle were homogenized under the same conditions used to prepare binding proteins of the nervous tissue. Since muscle has no particulate binding activity, only the soluble fraction was used. $D$, Extracts of Aplysia embryos were prepared as described in Materials and Methods. Particulate and soluble components were not separated in these determinations. For each tissue, binding was determined in triplicate at each concentration. For nervous tissue $(A$, $B)$ and muscle $(C)$, each determination was repeated 3 times, and the data points represent the average of the 3 determinations. Only 1 determination, in triplicate, was carried out with the embryo extracts $(D)$. Lines generated by linear regression analysis were fitted to points chosen by eye to represent the highest and lowest plausible binding constants.

The activity of cAMP-dependent protein kinase, as measured by phosphorylation of the exogenous heptapeptide substrate, varies among the components of the nervous system tested (Table 2). It was greater in sensory cell bodies from the pleural ganglion than in the remainder of the ganglion's neural components $(p<0.001)$, and greater in the neuropil of the abdominal ganglion than in cell bodies $(p<0.001)$. Thus, the ratio of cAMP binding to cAMP-dependent kinase activity was not constant in all parts of the nervous system. We found it to be lowest in sensory neurons and in neuropil.

\section{Heterogeneity in $C A M P$-binding proteins}

The characteristics of the cAMP-binding reaction were determined for sensory neurons and for the neural components of all central ganglia, as well as for muscle and embryos. The binding activity in both sensory neurons and total neural components appeared to be heterogeneous (Fig. 3, $A, B$ ). In view of the work of Eppler et al. (1982) showing that Aplysia nervous tissue contains at least 5 distinct binding proteins, this result is expected. The Scatchard plots derived from the binding data indicate the presence of high- and low-affinity binding sites, with constants ranging from 0.04 to $0.25 \mu \mathrm{M}$ for soluble fractions and from 0.04 to $0.33 \mu \mathrm{M}$ for the particulate fractions. These values are comparable to binding constants measured in vertebrate ner- vous tissue (Walter et al., 1977, 1978). No differences in these parameters were observed between sensory neurons and the rest of the nervous tissue. In contrast, the binding activity in muscle seems less complex (Fig. $3 C$ ). It is soluble and behaves as a single population of binding sites with an estimated constant of $0.05 \mu \mathrm{M}$, consistent with the observation that only 1 major binding protein can be identified in buccal muscle by photoaffinity labeling (Eppler et al., 1982). The binding is heterogeneous in a homogenate of embryos (Fig. $3 D$ ), which is similar to neurons in having multiple ${ }^{32} \mathrm{P}-8-\mathrm{N}_{3}$ cAMP-binding proteins (Palazzolo, 1985).

\section{Occupancy: Extent of binding by endogenous CAMP}

The subcellular distribution studies with CAMP indicated that endogenous cAMP binds to proteins within the cell. The foregoing assays measure how much total cAMP-binding capacity is present in neurons. We next determined the proportion of cAMP-binding sites within the cell that are actually occupied by cAMP under various conditions of stimulation. To make this kind of measurement, we had to show, first, that the cAMP bound in the cell will remain associated with the protein during the extraction procedure, and, second, that after extraction, this endogenously bound cAMP can be made to exchange with a ${ }^{3} \mathrm{H}$-cAMP probe. 


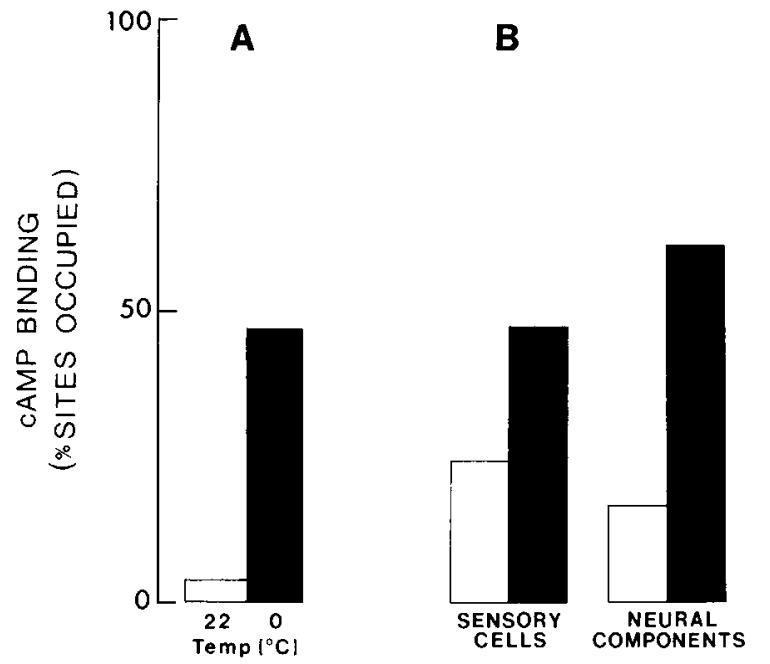

Figure 4. Occupancy of cAMP-binding sites in neural components. $A$, ${ }^{3} \mathrm{H}-\mathrm{cAMP}$ binding activity was measured in homogenates of untreated ganglia and of ganglia after exposure for $5 \mathrm{~min}$ to $10 \mu \mathrm{M}$ dibutyryl cAMP. One aliquot of the extracts was kept at $0^{\circ} \mathrm{C}$ (solid bar) and the other warmed to room temperature (open bar) before carrying out the binding reaction. Values represent the fraction of the control ${ }^{3} \mathrm{H}-\mathrm{cAMP}$ binding that is blocked after treatment with dibutyryl cAMP and are the means of 3 independent determinations. The SD of the measurements used to derive these values was less than $15 \%$ of their means. $B$, The extent of cAMP binding in vivo at rest (open bars) or after treatment with 5-HT (solid bars) was obtained by dividing the values in Table 1 for bound cAMP by those in Table 2 for the ${ }^{3} \mathrm{H}$-cAMP-binding capacity of sensory cells and the neural components of nervous tissue.

We treated intact abdominal ganglia with $\mathrm{N}_{6}, \mathrm{O}_{2}^{\prime}$-dibutyryl cAMP in order to increase the occupancy of the cAMP-binding proteins in the cells. Application of this analog of cAMP has previously been shown to enhance the release of transmitter from sensory neurons (Brunelli et al., 1976), presumably because the drug can penetrate and interact effectively with regulatory subunits of the cAMP-dependent protein kinase within the cells. We found that treatment with dibutyryl cAMP halved the amount of the ${ }^{3} \mathrm{H}$-cAMP probe bound, provided the homogenates were maintained at $0^{\circ} \mathrm{C}$ after extraction (Fig. $4 A$ ). This result indicates that dissociation of endogenously bound cAMP is negligible under these cold-trapping conditions, since dibutyryl cAMP is thought to bind preferentially only to 1 of the 2 cAMP-binding sites on the regulatory subunit (Rannels and Corbin, 1980; Doskeland et al., 1983). Consistent with this explanation, we find that $10 \mu \mathrm{M}$ dibutyryl cAMP only weakly inhibits photolabeling with ${ }^{32} \mathrm{P}-8-\mathrm{N}_{3} \mathrm{cAMP}$ (unpublished observation), an analog thought to be selective for the other cAMP binding site.

In contrast, when the homogenate from ganglia treated with the drug is incubated at $22^{\circ} \mathrm{C}$, the dibutyryl cAMP that had been bound within the cell exchanges with ${ }^{3} \mathrm{H}$-cAMP that is added in a saturating (excess) concentration: under these conditions no difference in ${ }^{3} \mathrm{H}$-cAMP binding was observed between the treated and control ganglia (Fig. $4 A$ ). Incubation at $22^{\circ} \mathrm{C}$ appears to result in equilibration of the sites with the ${ }^{3} \mathrm{H}$-cAMP probe, and therefore these conditions can be uscd to measure the ccll's total cAMP-binding capacity.

Since the values of bound cAMP in Table 1 were obtained under the cold-trapping conditions, and those of ${ }^{3} \mathrm{H}$-cAMPbinding capacity presented in Table 2 were determined at $22^{\circ} \mathrm{C}$, these data can be used to calculate the fraction of the cell's cAMP-binding sites that are occupied by cAMP in vivo. As shown in Figure 4B, exposure to 5-HT results in increased binding to a similar extent both in sensory cells and total neuronal components: the fraction of sites occupied is raised from approximately 20 to $60 \%$ of the total cAMP-binding capacity.

Like the ${ }^{3} \mathrm{H}$-cAMP probe, the photoactive analog of cAMP, ${ }^{32} \mathrm{P}-8-\mathrm{N}_{3} \mathrm{cAMP}$, can attach to unoccupied cAMP-binding sites (see Hoyer et al., 1980). Upon irradiation with ultraviolet light, the bound $8-\mathrm{N}_{3}$ cAMP becomes covalently linked; it therefore can also be used to assay the occupancy of individual kinase regulatory subunits. Eppler et al. (1982) previously used this photoaffinity label in Aplysia neural components to identify and characterize 5 distinct cAMP-binding proteins. These proteins are separated into 3 molecular-weight classes by 1 -dimensional SDS-PAGE: an $M_{r} 47,000$ and an $M_{r} 52,000$ class, each consisting of 2 distinct species, and a single $M_{r} 105,000$ protein (Eppler et al., 1982, 1986). As in the experiments with dibutyryl cAMP, we expect that, under cold-trapping conditions, endogenously bound cAMP will protect binding sites from subsequent in vitro labeling with the photoaffinity reagent and that $8-\mathrm{N}_{3}-$ cAMP will react only with the sites that had been unoccupied in the cell.

In order to examine the extent of occupancy within sensory cells, we stimulated the neurons by the 2 procedures used by Bernier et al. (1982) to study elevations of cAMP. We first examined homogenates of sensory neurons dissected from abdominal ganglia that had been exposed to a saturating concentration of 5-HT. Binding proteins from these cells were labeled less intensely by ${ }^{32} \mathrm{P}-8-\mathrm{N}_{3} \mathrm{cAMP}$ than were those from untreated ganglia. This inhibition of labeling (presumed to reflect enhanced intracellular occupancy of binding sites by the cAMP induced by 5-HT) was similar for each of the 3 molecular-weight classes of binding proteins, the average decrease being $66 \pm 9 \%$ $(n=3)$. One of these experiments is shown in Figure 5. In another set of experiments, we produced facilitation of sensory neurons by stimulating the connective electrically. Bernier et al. (1982) showed that this treatment, which is presumably more physiologically relevant, elevated cAMP in sensory neurons. In these experiments, we labeled aliquots of the homogenate under cold-trapping and equilibration conditions, and calculated the percentage occupancy of each binding protein as the extent to which its labeling is reduced in extracts maintained at $0^{\circ} \mathrm{C}$ (coldtrapping) compared to that obtained at $22^{\circ} \mathrm{C}$ (equilibrium conditions). All sensory cell clusters included in the stimulated group were shown to be physiologically sensitized: the duration of their action potential was increased by more than $35 \%$ (see Materials and Methods). An autoradiogram of one of these experiments is shown in Figure 6. Again, the stimulated cells showed significant occupancy of all 3 classes of binding protein (Fig. 6A). Labeling in the control ganglia was similar whether extracts were kept at 0 or at $22^{\circ} \mathrm{C}$ (Fig. $6 B$ ), indicating that the sites in these unstimulated cells are not occupied with endogenous cAMP.

In 6 experiments, the cAMP-binding sites in stimulated sensory cells showed an average occupany of $34 \%$ compared with $17 \%$ for control neurons (Fig. $7 A$ ). Two of the extracts from control ganglia showed high occupancy values, possibly because thesc particular groups of animals had been partially sensitized by previous experiments; nevertheless, connective shock increased occupancy within each of the groups of animals tested (Fig. $7 B$ ). Variation in the previous experience of animals is likely to complicate biochemical studies of the closely regulated molecules underlying memory and learning.

The extent of occupancy after the connective was stimulated 


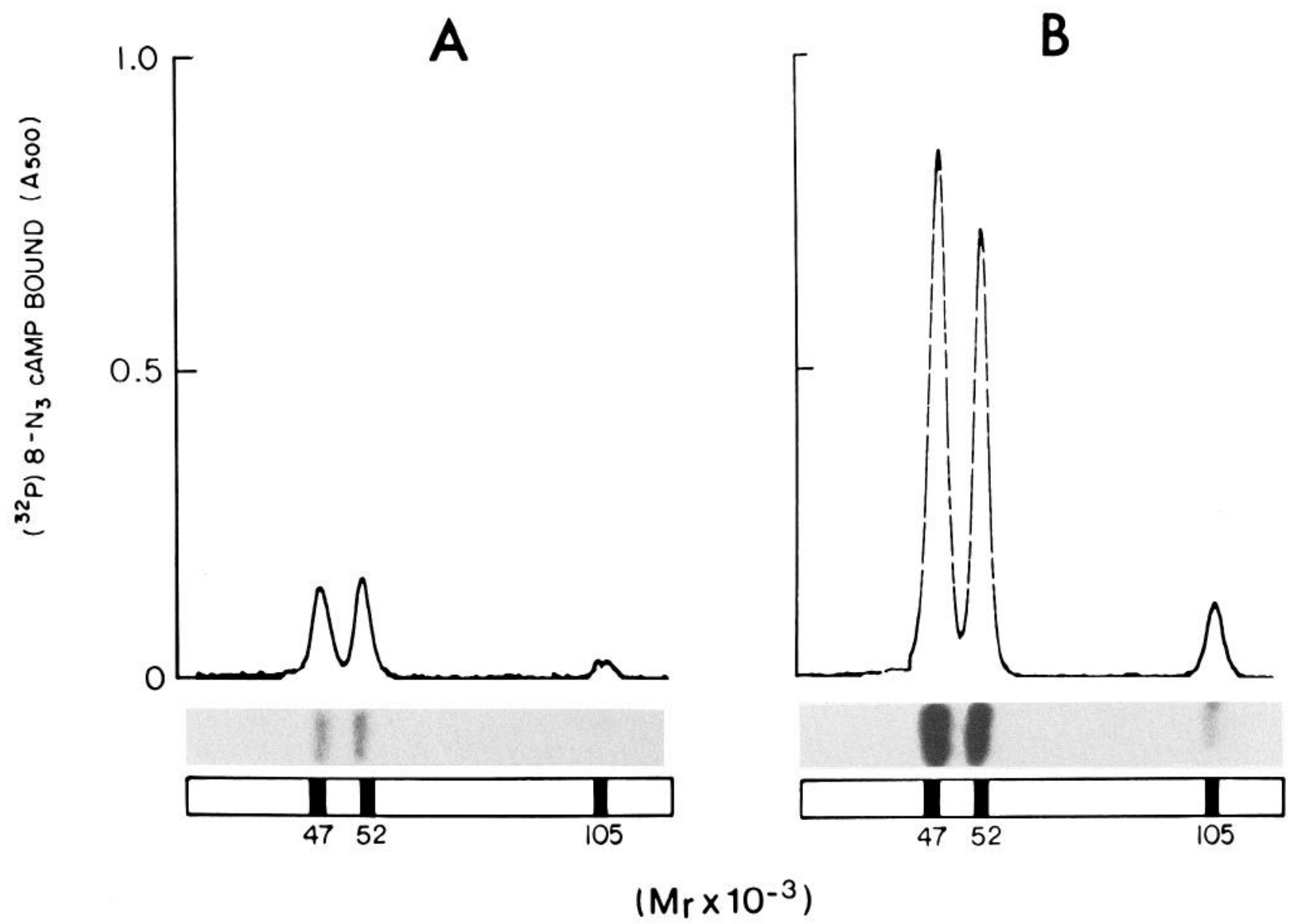

Figure 5. Effect of treating abdominal ganglia with 5-HT on subsequent ${ }^{32} \mathrm{P}-8-\mathrm{N}_{3} \mathrm{cAMP}$ labeling in sensory neurons. The proteins were labeled with ${ }^{32} \mathrm{P}-8-\mathrm{N}_{3} \mathrm{cAMP}$ at $0^{\circ} \mathrm{C}$ and separated by electrophoresis on a $6-12 \%$ gradient gel. Autoradiographs and densitometric traces of cAMP-binding proteins from the sensory neurons are shown. Identical samples of protein from 3 abdominal sensory neuron clusters were placed in each lane. $A$, Cells treated with $0.2 \mathrm{~mm} 5$-HT. B, Control cells.

was similar (31-39\%) for each of the 3 molecular-weight classes of cAMP-binding proteins (Fig. 7C). In cells from the control ganglia, however, the occupancy of binding sites varied considerably, ranging from an average of $3 \%$ for the $M_{r} 47,000$ species to $33 \%$ for the $M_{r} 105,000$ protein. Stimulation of the connective significantly elevated binding of intracellular cAMP to the $M_{r}$ 47,000 and 52,000 species but not to the $M_{r} 105,000$ protein. Thus, in ganglia from animals that have not been stimulated experimentally (controls), cAMP appears to be bound differentially, with preferential binding to the high-molecular-weight protein; stimulating the connective selectively elevates binding of cAMP to the other proteins.

\section{Discussion}

Castellucci et al. (1982) showed that the duration of short-term facilitation in Aplysia sensory neurons is determined by a persistently active protein kinase: injection of the specific kinase inhibitor from rabbit muscle abruptly ended the facilitation once the sensitization process had been initiated. Bernier et al. (1982) showed that the content of cAMP in sensory cells, which was initially elevated after a sensitizing stimulus, remained elevated over a period of $15 \mathrm{~min}$ and declined with a time course that paralleled the duration of the facilitation. Here we have shown that $85-90 \%$ of the cells' cAMP exists in a free (unbound) form both at rest and after stimulation. The elevated amounts of
cAMP in sensory cells are not present in a form protected from degradation, and this implies that the time course of the elevation is determined solely by the balance of adenylate cyclase and phosphodiesterase activities. Evidence that the persistent synthesis of cAMP by an activated cyclase complex produces this time course has been presented previously (Schwartz et al., 1983).

We are interested in cataloging the intracellular properties of the cAMP cascade that determine its role in mediating neuronal plasticity. In unstimulated sensory neurons, we found comparable amounts of cAMP (19.3 pmol/mg, Table 1$)$ and its intracellular binding proteins (12.7 pmol/mg, Table 2$)$. Stimulating treatments increased the cAMP bound to protein in sensory cells 2- to 3-fold according to 2 independent methods of assay: nitrocellulose filter binding (Fig. $4 B$ ) and inhibition of photoaffinity labeling (Fig. $7 A$ ). Since the elevation of bound cAMP revealed by these methods is similar in magnitude to the elevation of total cellular cAMP previously found to be induced by these treatments (Bernier et al., 1982), the cAMP-binding proteins within the cell must be operating over a linear portion of their binding curves.

This observation indicates that the regulatory subunits bind cAMP less avidly in the cell than in vitro. The concentration of cAMP in unstimulated sensory neurons can only be roughly estimated because of uncertainty in evaluating cell volume, but 


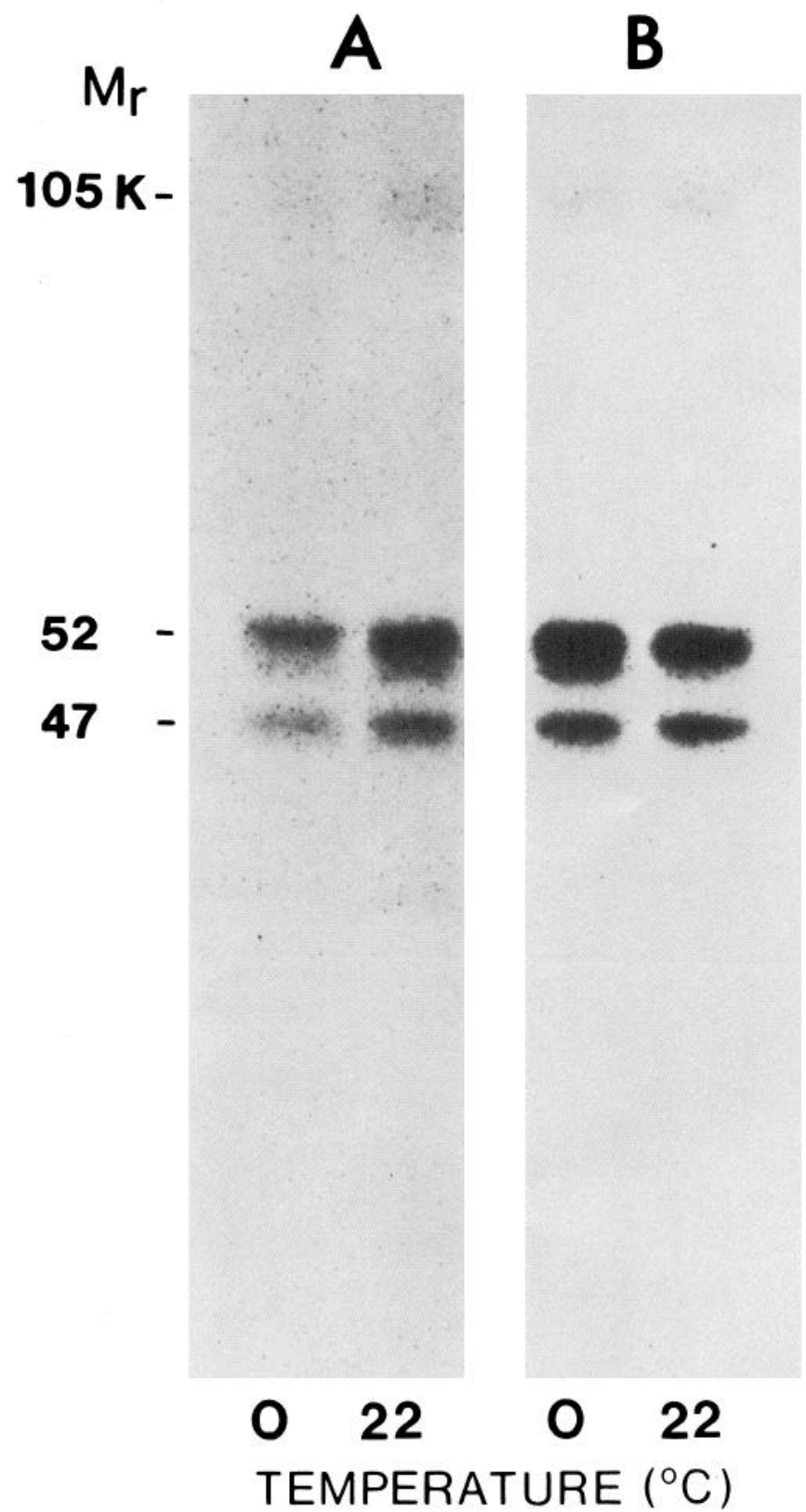

Figure 6. Binding of endogenous cAMP in sensory neurons. Less than $1 \mathrm{~min}$ after an electrical shock was delivered to the connective, ganglia were rapidly frozen in 50\% propylene glycol. Sensory clusters from 3 stimulated (lanes 1 and 2) or control (lanes 3 and 4 ) ganglia were dissected and homogenized at $0^{\circ} \mathrm{C}$ in $5 \mathrm{~mm} 2$-mercaptoethanol, $0.2 \%$ saponin, $0.35 \mathrm{~m}$ sucrose, $0.17 \mathrm{~m} \mathrm{NaCl}, 3 \mathrm{~mm}$ EDTA, $1 \mathrm{~mm}$ EGTA, and $20 \mathrm{~mm}$ Tris- $\mathrm{HCl}$ ( $\mathrm{pH}$ 7.4). Aliquots were first incubated for $10 \mathrm{~min}$ with $0.6 \mu \mathrm{M}{ }^{32} \mathrm{P}-8-\mathrm{N}_{3} \mathrm{CAMP}$ either at $0^{\circ} \mathrm{C}$ (lanes 1 and 3) or at $22^{\circ} \mathrm{C}$ (lanes 2 and 4). Both samples were then kept for another $10 \mathrm{~min}$ at $0^{\circ} \mathrm{C}$, followed by a $5 \mathrm{~min}$ period of photolabeling with ultraviolet light. (Samples that had been kept at $0^{\circ} \mathrm{C}$ were subsequently warmed to $22^{\circ} \mathrm{C}$ for an additional $10 \mathrm{~min}$ to compensate for any proteolysis that might have occurred at the higher temperature.) Proteins were separated by gel electrophoresis, stained with the BioRad silver reagent, and autoradiographed for $96 \mathrm{hr}$ at $-70^{\circ} \mathrm{C}$. Decreased photolabeling at $0^{\circ} \mathrm{C}$ relative to $22^{\circ} \mathrm{C}$ represents an increase in binding of endogenous cAMP.

it appears to be in the micromolar range (see Hockberger and Yamane, 1984), a value exceeding the highest in vitro binding constant that we measured in neuronal extracts (Fig. 3). Beavo et al. (1974), in discussing the similar values that they found for the concentration and the binding of cAMP in rabbit muscle, suggested that the effective (in vivo) binding constant is higher than the apparent (in vitro) constant. On explanation offered was that a significant amount of the total cAMP in the cell is taken up by the binding proteins. The amount of cAMP that is bound at saturation in Aplysia, however, does not greatly diminish the content of the free cyclic nucleotide within the cell (compare the values for free and bound cAMP in Table 1). Rather, it would appear that the high concentration of kinase and relatively low concentration of substrate in the cell promote reassociation of the subunits to the holoenzyme with release of cAMP; thus both the effective binding and activation constants are raised under intracellular conditions (see, for example, Granot et al., 1980).

We find that different cells and different subcellular components from the Aplysia nervous system vary substantially in their relative amounts of cAMP-binding and cAMP-dependent protein kinase activity. Though it has been reported that untransformed cells contain equimolar amounts of regulatory and catalytic subunits (Corbin et al., 1977; Hofmann et al., 1977), the ratio of the subunits has not, to our knowledge, been determined for the various regions and subcellular components of vertebrate nervous tissues. Walter et al. (1978) found that regions of normal rat brain vary from one another with respect to amounts of $R_{I}$ and $\mathrm{R}_{\mathrm{II}}$ regulatory subunits; in addition, transformed cells (Walter et al., 1979; Erlichman et al., 1984), as well as differentiating granulosa cells (Richards et al., 1984), maintain a molar excess of regulatory to catalytic subunit under certain conditions. In Aplysia nervous tissue we found that sensory cells had the lowest ratio of binding to kinase activity, while the neuropil had a lower ratio than did the cell bodies. We suggest that a stoichiometric excess of regulatory subunits to catalytic subunits would result in a cell less sensitive to cAMP. At any subsaturating concentration of cAMP, free regulatory subunits would recombine with catalytic subunits to diminish the extent of kinase activation. Although we have not shown this enhanced sensitivity in Aplysia sensory neurons directly, Schwechheimer and Hofmann (1977) used the enzyme purified from rabbit skeletal muscle to demonstrate that the presence of greater than stoichiometric amounts of regulatory subunit raises the activation constant of the kinase.

Sensory neurons are capable of mediating a variety of simple forms of learning (both short- and long-term sensitization and habituation, as well as associative, classical, and operant conditioning), and 2 of these forms, sensitization and classical conditioning, involve changes in the cAMP-dependent protein phosphorylation (Kandel and Schwartz, 1982; Hawkins et al., 1985). Are sensory neurons endowed with a special cAMPdependent kinase to mediate these learning processes? If the lower ratio of regulatory to catalytic activities that we found in sensory cells results in a more sensitive kinase system, we would argue that sensory cells are poised to respond to smaller changes in cAMP. In other cells, where the concentration of regulatory subunits is in excess, relatively large amounts of the second messenger would need to be accumulated to bring about changes in protein phosphorylation.

The properties of the cAMP-binding proteins in sensory cells do not appear to differ from those in other neurons. cAMP is bound within sensory and other neurons to a similar extent (Figs. $2,4 B$ ), and with similar affinities and capacities in vitro (Fig. 3 , Table 2). Sensory neurons also contain the same set of ${ }^{32} \mathrm{P}-\mathrm{N}_{3}$ cAMP-labeled proteins that can be separated by 2-dimensional 


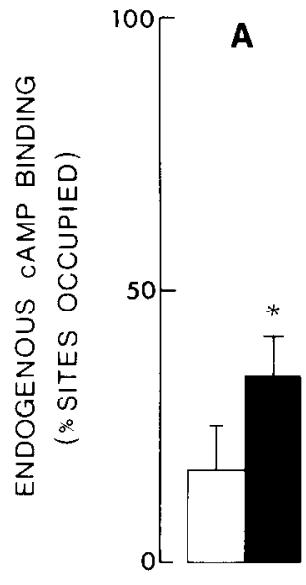

Total

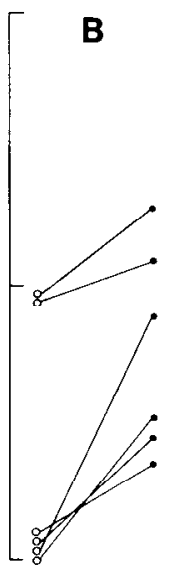

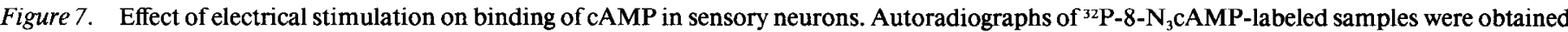

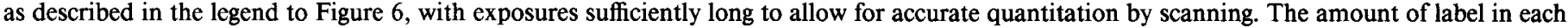

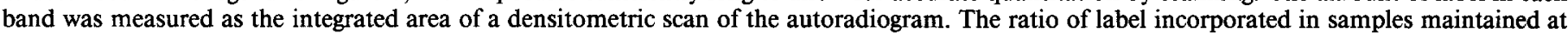

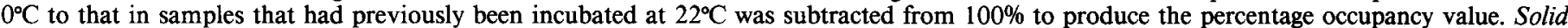

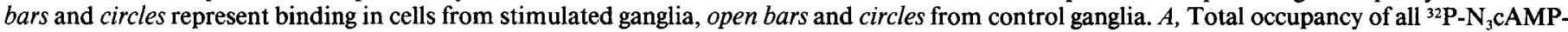

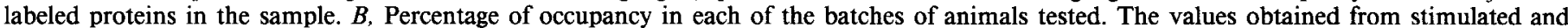

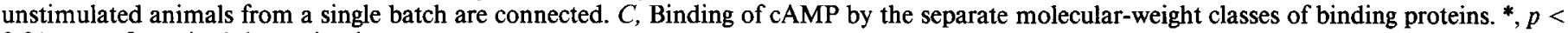
0.01 ; $t$ test for paired determinations.

gel electrophoresis as does the rest of the nervous system (unpublished observations). cAMP regulates different $\mathrm{K}^{+}$channels in several Aplysia neurons: the $\mathrm{K}_{\mathrm{s}}^{+}$channel in sensory neurons (Siegelbaum et al., 1982; Pollock et al., 1985), several $\mathrm{K}^{+}$channels in the neurosecretory bag cells (Strong and Kaczmarek, 1986), and an anomalously rectifying $\mathrm{K}^{+}$channel in $\mathrm{R} 15$ (Benson and Levitan, 1983). If one or more of the neuron-specific kinases are indeed specialized for modulating ion channels, it is not surprising that they are present in both sensory and other neurons. The learning that sensory cells mediate is only one possible behavioral outcome of the regulation of ion channels and would not necessarily require a unique type of kinase.

The 3 molecular-weight classes of cAMP-binding proteins that are resolved by 1 -dimensional gel electrophoresis all bind cAMP after exposure to 5-HT or connective stimulation (Figs. $5,6)$. Neither treatment results in total occupancy of all protein binding sites with cAMP. We suspect that the binding falls short of saturation because these treatments do not elevate the intracellular cAMP enough at the times tested. It is also possible that some endogenously bound cAMP exchanges with the ${ }^{32} \mathrm{P}$ $\mathrm{N}_{3}$ cAMP probe, although exchange at $0^{\circ} \mathrm{C}$ has been reported to have a half-time on the order of days for vertebrate regulatory subunits (Hoyer et al., 1980). Moreover, bound dibutyryl cAMP did not appear to exchange with ${ }^{3} \mathrm{H}$-cAMP under our conditions of isolation (Fig. 4A). In addition, loss of endogenously bound cAMP from Aplysia proteins is negligible at $0^{\circ} \mathrm{C}$ (see Materials and Methods).

A question of physiological importance is whether cAMPdependent kinases formed from the different regulatory subunits can be selectively activated. It has been shown that certain drugs that elevate CAMP can increase the binding and the kinase activity of only 1 of the 2 vertebrate types of kinase $\left(R_{I}\right.$ or $\left.R_{I I}\right)$ (Litvin et al., 1984; Chew, 1985) or of the enzyme situated in a particulate rather than in a soluble compartment (Buxton and Brunton, 1983). This selectivity may result from compartmentalization of the newly formed cAMP. We have presented evi- dence that the elevated cAMP in Aplysia sensory neurons that results from stimulating the connective can also be bound selectively: This input raises the occupancy of the proteins in the $M_{r} 47,000$ and 52,000 classes but does not affect the occupancy of the $M_{r} 105,000$ protein (Fig. $7 C$ ). Because the $M_{r} 47,000$ and 52,000 bands on the gels each contain 2 distinct protein species (Eppler et al., 1982), we could not measure the occupancy of each of the 5 cAMP-binding proteins separately; some additional selectivity thus must be obscured. Our data indicate that the $M_{r} 105,000$ species binds substantial amounts of cAMP in the sensory neurons from unstimulated animals but does not bind more cAMP in response to connective shock. The cAMP produced in response to the treatment with a saturating concentration of 5-HT, in contrast, was bound nonselectively by all 3 molecular-weight classes of binding protein (Fig. 5), implying that the 2 treatments differ with respect to their effects on adenylate cyclase.

It is attractive to think that only 1 type of cAMP-dependent kinase is the effector in the sensory neuron terminal for the specific protein modification underlying short-term sensitization. Another task for a distinctive form of regulatory subunit might be to serve as the intracellular messenger for instructing the nucleus of the sensory cell to alter its gene expression. A change in gene expression has frequently been proposed as the mechanism for converting short-term memory to the longterm form (see Kandel and Schwartz, 1982). The enhanced potential for protein phosphorylation postulated to account for long-term sensitization in sensory neurons (Kandel and Schwartz, 1982) might be produced by changes in the cell's population of regulatory subunits. Changes in populations of regulatory subunits have been reported in many cell types (Lohmann and Walter, 1984).

\section{References}

Abrams, T. W., V. F. Castellucci, J. S. Camardo, E. R. Kandel, and P. E. Lloyd (1984) Two endogenous neuropeptides modulate the gill 
and siphon withdrawal reflex in Aplysia by presynaptic facilitation involving cAMP-dependent closure of a serotonin-sensitive potassium channel. Proc. Natl. Acad. Sci. USA 81: 7956-7960.

Ambron, R. T., J. E. Goldman, and J. H. Schwartz (1975) Effect of inhibiting protcin synthesis on axonal transport of membrane glycoproteins in an identified neuron of Aplysia. Brain Res. 94: 307323.

Beavo, J. A., P. J. Bechtel, and E. G. Krebs (1974) Activation of protein kinase by physiological concentrations of cyclic AMP. Proc. Natl. Acad. Sci. USA 71:3580-3583.

Benson, J. A., and I. B. Levitan (1983) Serotonin increases an anomalously rectifying $\mathrm{K}^{+}$current in the Aplysia neuron R15. Proc. Natl. Acad. Sci. USA 80: 3522-3525.

Bernier, L. (1984) Cyclic AMP in the nervous system of Aplysia and its role in synaptic function. Doctoral dissertation, Columbia University, New York, NY.

Bernier, L., V. F. Castellucci, E. R. Kandel, and J. H. Schwartz (1982) Facilitatory transmitter causes a selective and prolonged increase in adenosine $3^{\prime}: 5^{\prime}$-monophosphate in sensory neurons mediating the gill and siphon withdrawal reflex in Aplysia. J. Neurosci. 2: 1682-1691.

Brunelli, M., V. F. Castellucci, and E. R. Kandel (1976) Synaptic facilitation and behavioral sensitization in Aplysia: Possible role of serotonin and cyclic AMP. Science 194: 1178-1181.

Buxton, I. L. O., and L. L. Brunton (1983) Compartments of cyclic AMP and protein kinase in mammalian cardiomyocytes. J. Biol. Chem 258: 10,233-10,239.

Byrne, J. H., V. F. Castellucci, and E. R. Kandel (1974) Receptive fields and response properties of mechanoreceptor neurons innervating siphon skin and mantle shelf in Aplysia. J. Neurophysiol. 37 1041-1064.

Castellucci, V. F., and E. R. Kandel (1976) Presynaptic facilitation as a mechanism for behavioral sensitization in Aplysia. Science 194 1176-1178.

Castellucci, V. F., E. R. Kandel, J. H. Schwartz, F. D. Wilson, A. C. Nairn, and P. Greengard (1980) Intracellular injection of the catalytic subunit of cyclic AMP-dependent protein kinase simulates facilitation of transmitter release underlying behavioral sensitization in Aplysia. Proc. Natl. Acad. Sci. USA 77: 7492-7496.

Castellucci, V. F., A. Nairn, P. Greengard, J. H. Schwartz, and E. R. Kandel (1982) Inhibitor of adenosine 3':5'-monophosphate-dependent protein kinase blocks presynaptic facilitation in Aplysia. J. Neurosci. 2: 1673-1681.

Cedar, H., and J. H. Schwartz (1972) Cyclic adenosine monophosphate in the nervous system of Aplysia californica. II. Effect of serotonin and dopamine. J. Gen. Physiol. 60:570-587.

Chew, C. S. (1985) Parietal cell protein kinases: Selective activation of type I cAMP-dependent protein kinase by histamine. J. Biol. Chem. 260: 7540-7550.

Corbin, J. D., P. H. Sugden, T. M. Lincoln, and S. L. Keely (1977) Compartmentalization of adenosine $3^{\prime}: 5^{\prime}$-monophosphate dependent protein kinase and granulosa cell responsiveness to gonadotropins. Endocrinology 114: 2190-2198.

Doskeland, S. O., D. Ogreid, R. Ekanger, P. A. Sturm, J. P. Miller, and R. H. Suva (1983) Mapping of the two intrachain cyclic nucleotide binding sites of adenosine cyclic $3^{\prime}, 5^{\prime}$-phosphate dependent protein kinase I. Biochemistry 22: 1094-1101.

Eisenstadt, M., J. E. Goldman, E. R. Kandel, H. Koike, J. Koester, and J. H. Schwartz. (1973) Intrasomatic injection of radioactive precursors for studying transmitter synthesis in identified neurons of Aplysia californica. Proc. Natl. Acad. Sci. USA 70: 3371-3375.

Eppler, C. M., M. J. Palazzolo, and J. H. Schwartz (1982) Characterization and localization of adenosine $3^{\prime}: 5^{\prime}$-monophosphate-binding proteins in the nervous system of Aplysia. J. Neurosci. 2: 1692-1704.

Eppler, C. M., H. Bayley, S. M. Greenberg, and J. H. Schwartz (1986) Structural studies on a family of cAMP-binding proteins in the nervous system of Aplysia. J. Cell Biol. 102: 320-321.

Erlichman, J., Y. Litvin, and N. Fleischer (1984) Immunological and molecular characterization of the cAMP-dependent protein kinase in AtT20 cells. J. Biol. Chem. 259: 10,289-10,295.

Flockhart, D. A., and J. D. Corbin (1982) Regulatory mechanisms in the control of protein kinases. CRC Crit. Rev. Biochem. 12: 133186

Granot, J., A. S. Mildvan, K. Hiyama, H. Kondo, and E. T. Kaiser (1980) Magnetic resonance studies on the effect of the regulatory subunit on metal and substrate binding to the catalytic subunit of bovine heart protein kinase. J. Biol. Chem. 255: 4569-4573.

Hawkins, R. D., V. F. Castellucci, and E. R. Kandel (1981) Interneurons involved in mediation and modulation of gill-withdrawal reflex in Aplysia. II. Identified neurons produce heterosynaptic facilitation contributing to behavioral sensitization. J. Neurophysiol. 45: 315326.

Hawkins, R. D., G. A. Clark, and E. R. Kandel (1985) Operant conditioning and differential classical conditioning of gill withdrawal in Aplysia. Soc. Neurosci. Abstr. 11: 796 .

Hockberger, P., and T. Yamane (1984) Measurement of cyclic AMP concentration in Aplysia nerve cell bodies. Soc. Neurosci. Abstr. 10: 896.

Hofmann, F., P. J. Bechtel, and E. G. Krebs (1977) Concentration of cyclic AMP-dependent protein kinase subunits in various tissues. $\mathrm{J}$. Biol. Chem. 252: 1441-1447.

Hoyer, P. B., J. R. Owens, and B. E. Haley (1980) The use of photoaffinity probes to elucidate molecular mechanisms of nucleotideregulated phenomena. Ann. NY Acad Sci. 346: 280-301.

Kandel, E. R., and J. H. Schwartz (1982) Molecular biology of learning: Modulation of transmitter release. Science 218: 433-443.

Klein, M., and E. R. Kandel (1978) Presynaptic modulation of voltagedependent $\mathrm{Ca}^{2+}$ current: Mechanism for behavioral sensitization in Aplysia californica. Proc. Natl. Acad. Sci. USA 75: 3512-3516.

Litvin, Y., R. Pasmantier, N. Fleisher, and J. Erlichman (1984) Hormonal activation of the cAMP-dependent protein kinases in AtT20 cells: Preferential activation of protein kinase I by corticotropin releasing factor, isoprotonol, and forskolin. J. Biol. Chem. 259: 10,29610,302 .

Lohmann, S. M., and U. Walter (1984) Regulation of the cellular and subcellular concentrations and distribution of cyclic nucleotide-dependent protein kinases. Adv. Cyclic Nucleotide Res. 18: 63-117.

Lowry, O. H., N. J. Rosebrough, A. L. Far, and R. J. Randall (1951) Protein measurement with the folin reagent. J. Biol. Chem. 193:265275.

Nestler, E. J., and P. Greengard (1984) Protein Phosphorylation in the Nervous System, Wiley, New York.

Palazzolo, M. J. (1985) Third messenger molecules in Aplysia. Doctoral dissertation, Columbia University, New York, NY.

Pollock, J. D., L. Bernier, and J. S. Camardo (1985) Serotonin and cyclic adenosine $3^{\prime}: 5^{\prime}$-monophosphate modulate the potassium current in tail sensory neurons in the pleural ganglion of Aplysia. J. Neurosci. 5: 1862-1871.

Rannels, S. R., and J. D. Corbin (1980) Two different intrachain cAMP binding sites of cAMP-dependent protein kinases. J. Biol. Chem. 255 7085-7088.

Richards, J. S., M. Haddox, J. S. Tash, U. Walter, and S. Lohmann (1984) Adenosine 3':5'-monophosphate dependent protein kinase and granulosa cell responsiveness to gonadotropins. Endocrinology 114: 2190-2198.

Saitoh, T., and J. H. Schwartz (1983) Serotonin alters the subcellular distribution of $\mathrm{Ca}^{2+} /$ calmodulin binding protein in neurons of Aplysia. Proc. Natl. Acad. Sci. USA. 80: 6708-6712.

Schwartz, J. H., L. Bernier, V. F. Castellucci, M. Palazzolo, T. Saitoh, A. Stapleton, and E. R. Kandel (1983) What molecular steps determine the time course of the memory for short-term sensitization in Aplysia? Cold Spring Harbor Symp. Quant. Biol. 48: 811-819.

Schwechheimer, K., and F. Hofmann (1977) Properties of regulatory subunits of cyclic AMP-dependent protein kinase (peak I) from rabbit skeletal muscle prepared by urea treatment of the holoenzyme. J. Biol. Chem. 252: 3854-3861.

Siegelbaum, S. A., J. S. Camardo, and E. R. Kandel (1982) Serotonin and cyclic AMP close single $\mathrm{K}^{+}$channels in Aplysia sensory neurones. Nature 299: 413-417.

Strong, J. A., and L. K. Kaczmarek (1986) Multiple components of delayed potassium current in peptidergic neurons of Aplysia: Modulation by an activator of adenylate cyclase. J. Neurosci. 6: 814-822.

Sugden, P. H., and J. D. Corbin (1976) Adenosine 3',5'-cyclic monophosphate-binding proteins in bovine and rat tissues. J. Biochem. 159: 423-437.

Terasaki, W. L., and G. Brooker (1977) Cardiac adenosine 3':5'-monophosphate free and bound forms in the isolated rat atrium. J. Biol Chem. 252: 1041-1050.

Walter, U., M. R. C. Costa, X. O. Breakefield, and P. Greengard (1979) 
Presence of free cyclic AMP reactor protein and regulation of its level by cyclic AMP in neuroblastoma $\times$ glioma hybrid cells. Proc. Natl. Acad. Sci. USA 76: 3251-3255.

Walter, U., P. Kanof, H. Schulman, and P. Greengard (1978) Adenosine $3^{\prime}: 5^{\prime}$-monophosphate receptor proteins in mammalian brain. J. Biol. Chem. 253: 6275-6280.

Walter, U., I. Uno, A. Y.-C. Liu, and P. Greengard (1977) Identifi- cation, characterization, and quantitative measurement of cyclic AMP receptor proteins in cytosol of various tissues using a photoaffinity ligand. J. Biol. Chem. 252: 6494-6500.

Walters, E. T., J. H. Byrne, T. J. Carew, and E. R. Kandel (1983) Mechanoafferent neurons innervating tail of Aplysia. I. Response properties and synaptic connections. J. Neurophysiol. 50: 1522-1542. 